DOI: https://doi.org/10.32839/2304-5809/2021-3-91-75

УДК 339.92:330.341.1:620.92

Корінний С.О., Бондаренко А.Г., Міхайлуца М.К.

Запорізький національний університет

\title{
ТЕНДЕНЦІЇ РОЗВИТКУ СОНЯЧНОЇ ТА ВІТРОВОЇ ЕНЕРГІЇ
}

\begin{abstract}
Анотація. В статті досліджуються тенденції розвитку сонячної та вітрової енергії. Аналізується перехід від традиційних джерел енергії до відновлюваних. Зазначається необхідність впровадження чистих джерел енергії через кліматичні зміни, які спричинені надмірним використанням викопного палива, що зумовлюе зростанню обсягу шкідливих викидів в атмосферу планети. Згадуються ратифіковані домовленості між країнами світу, метою яких є зменшення кліматичних змін шляхом переходу до відновлюваних джерел енергії (ВДЕ). Розглядається зростання частки сонячної та вітрової енергії в загальному обсязі генерації електроенергії. Висвітлюеться стан інвестування у розвиток ВДЕ, зокрема, сонячної та вітрової енергії. Відзначаються причини та можливості подальшого зростання частки сонячної та вітрової енергії в загальному обсязі генерації електроенергії.
\end{abstract}

Ключові слова: ВДЕ, генерація, сонячна та вітрова енергія, науково-технологічний прогрес, інвестиції, електроенергія.

Korinnyi Sergii, Bondarenko Anastasia, Mikhailutsa Mariia Zaporizhia National University

\section{SOLAR AND WIND ENERGY DEVELOPMENT TRENDS}

Summary. The article investigates the trends in the development of solar and wind energy. The transition from traditional to renewable energy sources is analyzed for a number of reasons: economic and political influence of countries that possess fossil resources on countries that depend on the import of such, climate change and the depletion of natural resources. The need for the introduction of clean energy sources due to climate change, which is caused by excessive use of fossil fuels, which in turn leads to an increase in harmful emissions into the planet's atmosphere, is designated. Ratified agreements between countries around the world, which aim to reduce climate change by switching to renewable energy sources (RES), are mentioned. The information on "smart" cities, which have set themselves the goal in the near future to switch to $100 \%$ use of clean energy sources, is given. The growth of the share of solar and wind energy in the total volume of electricity generation over the last 30 years is considered and the indicators starting from 2009 are analyzed. The data of the above energy sources in different regions of the world is compared. Attention is drawn to the fact that Europe is a region in which the share of solar and wind energy generation is growing rapidly. The state of investment in the development of RES, including solar and wind energy, is highlighted. The volumes of investment flows by the countries of the world in which they are the largest are revealed. It is noted that the largest country in terms of investment in RES is China. The data on investments in solar and wind energy for the last two years is compared. The reasons and possibilities of further growth of the share of solar and wind energy in the total amount of electricity generation are noted. In particular, it is highlighted that the cost of generating the above energy tends to decrease. The cost of generation of traditional (gas, nuclear energy) energy sources is compared with solar and wind. Emphasis is placed on the use of the latest technologies that will help reduce the cost of this energy and accelerate the process of its implementation. It is said that investors are interested in investing in RES because of the opportunity to further capture more market share and lobby their own interests.

Keywords: RES, generation, solar and wind energy, scientific and technological progress, investments, electricity.

$\Pi$ остановка проблеми. В наш час людство приділяе більше уваги питанню переходу від брудних джерел енергії до чистих відновлюваних. Генерація енергії вагомо впливає на природне середовище. Спалювання викопного палива збільшує викиди $\mathrm{CO}_{2}, \mathrm{CO}$, оксидів азоту та інших забруднюючих речовин. Видобуток вугілля й торфу призводять до зміни та руйнації ландшафртів. Розливи нафрти та нафртопродуктів знищують живу природу на великих територіях. Будівництво великих ГЕС призводить до зникнення багатьох видів риби, лісів, родючих земель. Атомна енергетика є небезпечною через можливі аварії, котрі спричиняють викиди радіоактивних речовин в оточуюче середовище. Також, переробка ядерних відходів та їх сховища не мають вирішення й вони несуть загрозу тисячі років.

Вищезгадані причини використання традиційних джерел енергії спонукають людство шу- кати більш безпечні джерела енергії. Тому останніми роками ми можемо спостерігати стрімкий розвиток відновлюваних джерел енергії (ВДЕ), особливо сонячної та вітрової енергії.

Аналіз останніх досліджень та публікацій. Питання розвитку ВДЕ $є$ актуальним серед дослідників. Наприклад, Череп А.В та Циганок К.О. вивчали особливості різних видів альтернативних джерел 3 позицї використання ресурсів та їх ефективності на підприемствах, а також розглядали перспективи впровадження зазначених джерел в Україні [1]. Нараєвський С.В. приділяв увагу едективності в роботі сонячної та вітрової енергетики за певними напрямками, такими як: використання потужностей, інвестиційних коштів та праці персоналу і на основі цього зробив порівняльний аналіз [2].

Виділення невирішених раніше частин загальної проблеми. Необхідність у розвитку та інвестуванні у сонячну та вітряну енергетику 


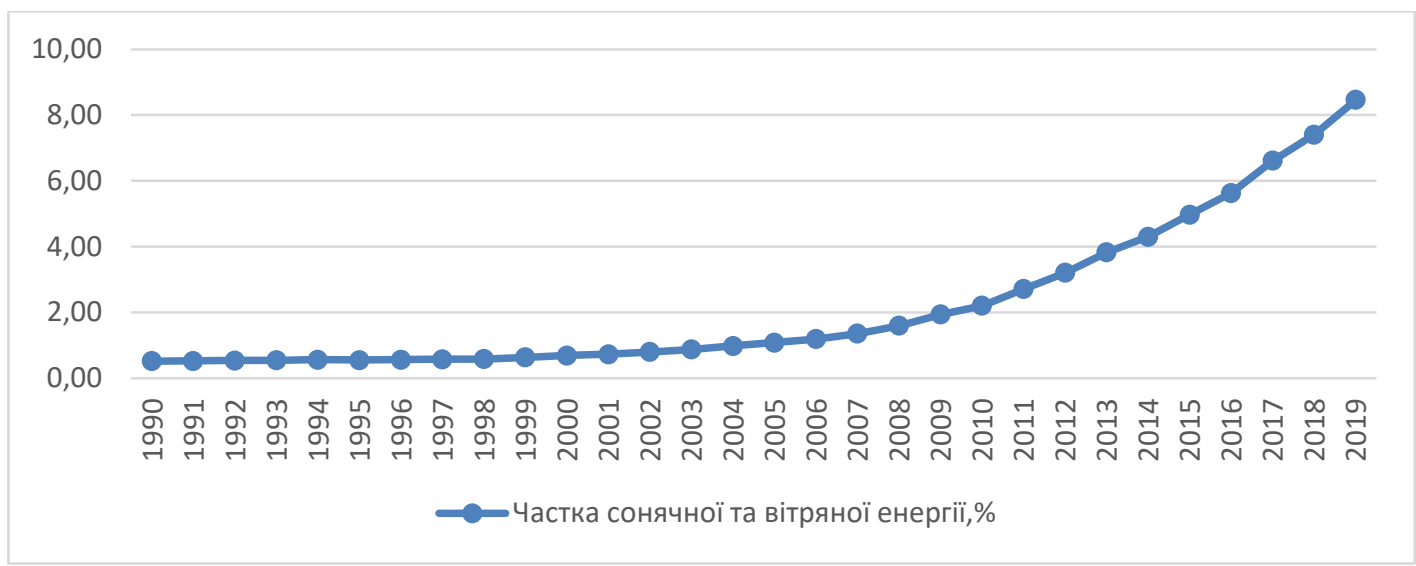

Рис. 1. Динаміка частки сонячної та вітрової енергії в світі у загальному обсязі генерації електроенергії, 1990-2019 pp.

Джерело: створено авторами за даними [3]

через проблеми, які виникають при використанні традиційних джерел енергії.

Формулювання цілей статті. Метою статті $є$ дослідити тенденції розвитку сонячної та вітрової енергії у сучасному світі.

Виклад основного матеріалу дослідження. Кінець XX - початок XXI століття можна охарактеризувати як період активізації економічних війн через конфрлікт інтересів країн, що володіють викопними енергетичними ресурсами та тих країн, котрі залежать від імпорту цих ресурсів. 3 часом ці протиріччя зростають й набувають більшої напруженості у відносинах між державами світу. Використання ембарго на продаж нафрти та газу найчастіше стає економіко-політичним інструментом впливу. Також, фракт вичерпності вищезазначених ресурсів та негативні наслідки для клімату планети від їх використання, спонукають суспільство переходити на ВДЕ. Останнім часом більшого розвитку зазнали такі ВДЕ, як сонячна та вітрова енергія (рис. 1).

3 рисунку 1 ми можемо бачити, що стрімке зростання частки сонячної та вітрової енергії в світі у загальному обсязі генерації електроенергії починається з 2009 року. Початкове значення цього показника становило 1,94\% у 2009 році, а станом на 2019 рік - 8,47\%, тобто за останне десятиліття зростання відбулось на $6,53 \%$ в загальному обсязі електроенергії або у 436,6\% власного зростання.

За даними статистичного видання Enerdata частка сонячної та вітрової енергії в світі у складі ВДЕ щорічно зростає. Станом на кінець 2019 року енергія сонця та вітру становить майже $32 \%$ від загальних ВДЕ (рис. 2).

3 кінця 80- $\mathrm{x}$ років XX століття почала з'являтися індормація щодо глобального потепління. Вчені визначають, що найголовнішим чинником, котрий спричиняе появу та розвиток вищезгаданого явища, е спалювання викопного палива, яке збільшуе концентрацію парникових газів. Тому, у 1992 році була підписана Рамкова конвенція ООН про зміну клімату (UNFCCC) 165 країнами світу. Метою цієї конвенції є розробка засобів та методів зменшення зміни клімату, а також шляхи адаптації до вже існуючих змін. На кінець 2019 року конвенцію ратифрікували 197 держав світу [4]. Одним 3 напрямків виконання конвенції є впровадження сонячних та вітрових електростанцій, використання яких по регіонах світу можна побачити на рисунку 3.

Як бачимо 3 рисунку 3 , більш стрімкими темпами частка сонячної та вітрової енергії зростає

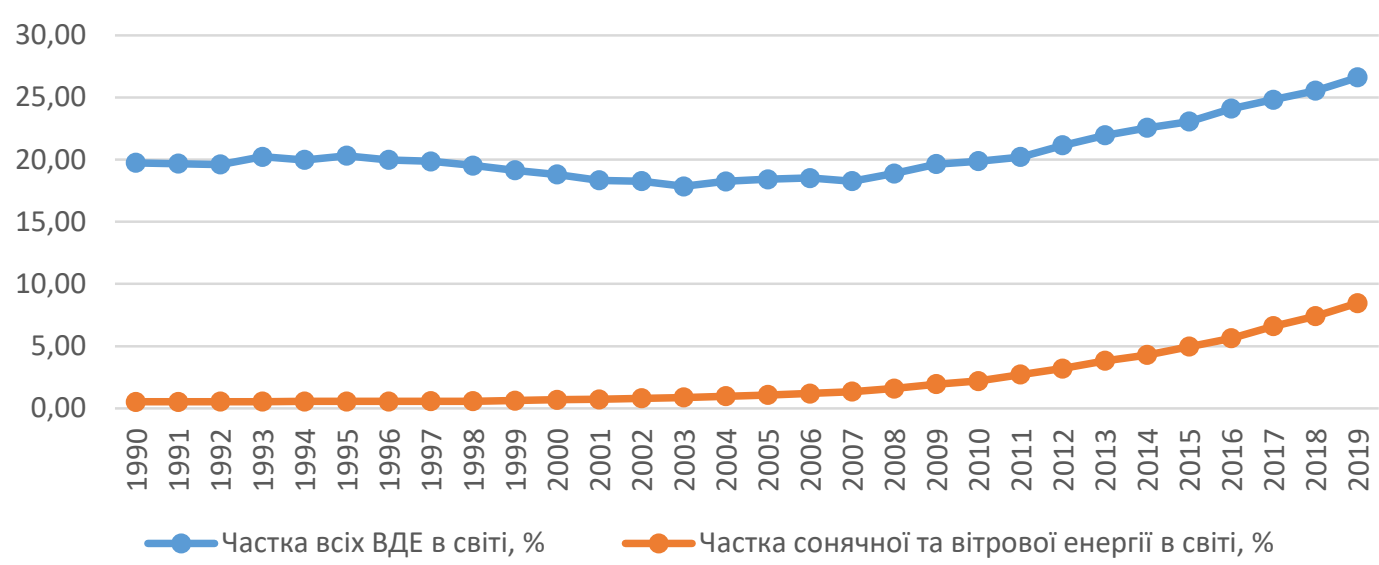

Рис. 2. Динаміка частки всіх ВДЕ й частки сонячної та вітрової енергії в світі у загальному обсязі виробництва електроенергії, 1990-2019 рр. 


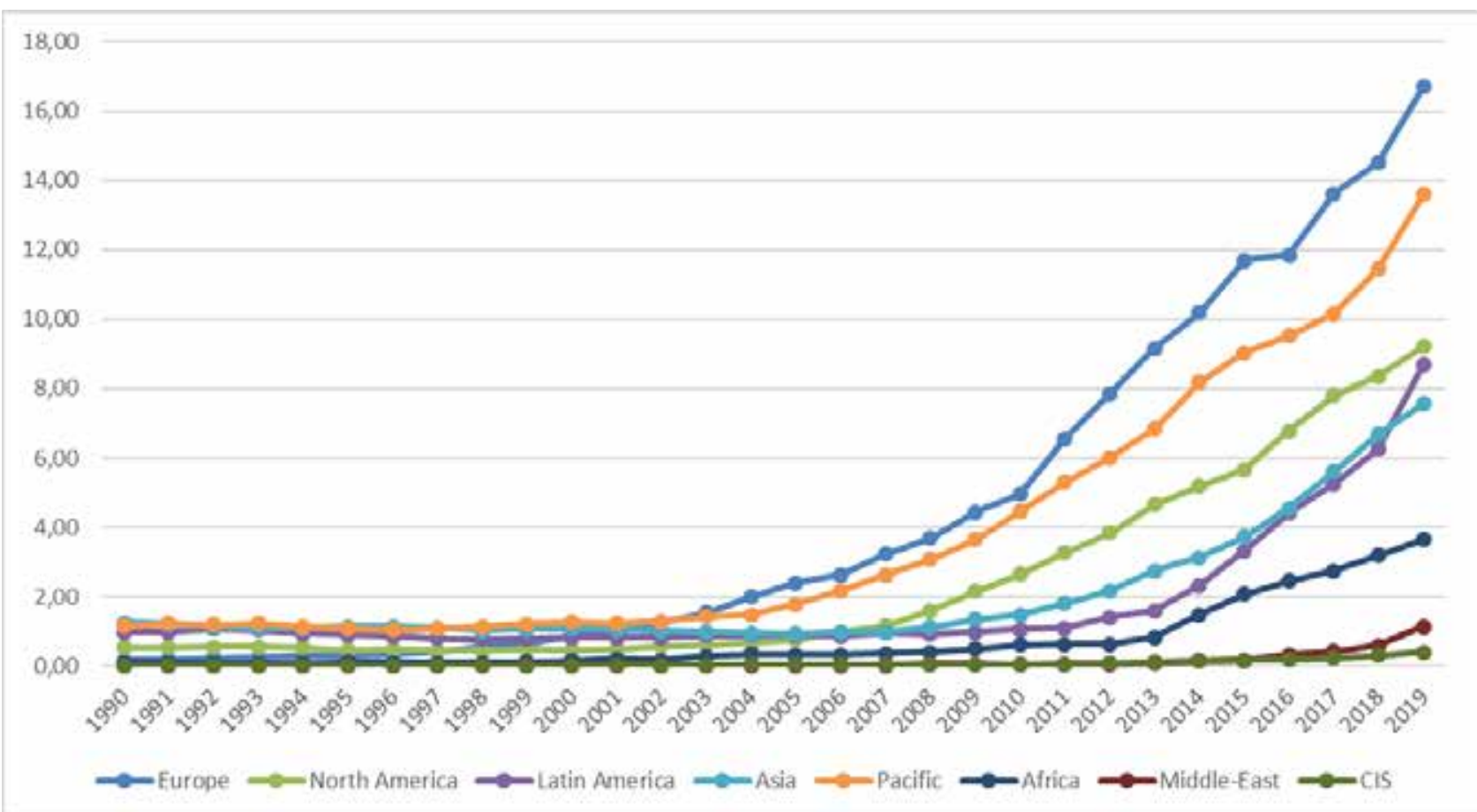

Рис. 3. Динаміка частки сонячної та вітрової енергї̈ від загального обсягу генерації електроенергії по регіонам світу, 1990-2019 рр.

Джерело: створено авторами за даними [3]

в країнах Свропи, в Тихоокеанському регіоні та у Північній Америці.

Також, кроком до зменшення змін клімату і переходу на ВДЕ стало підписання Угоди Мерів, що була запропонована Свропейською комісіею у 2008 рощі. Основним іiі напрямом $\epsilon$ підтримка діяльності місцевих органів влади в розробці та реалізації цілей СС щодо змін клімату та переходу до сталої енергетики. На разі більше 7000 міст в світі доєдналися до цієї угоди та впроваджують технології, що дозволять отримати $100 \%$ перехід на ВДЕ [5].
Новим напрямком у розвитку міст в багатьох країнах світу стало створення "розумних» міст, котрі дотримуються раціональних підходів до управління міською інфрраструктурою, використовуючи датчики аналізу даних. Керівництво таких міст акцентує увагу на зростанні якості життя населення та впровадженні новітніх технологій для їх розвитку, наприклад технологї щодо ВДЕ.

Пропонуемо розглянути топ- 10 «розумних» міст світу, які використовують ВДЕ згідно звіту «Міжнародні тенденції в галузі відновлюваних джерел енергії» компанії Deloitte (рис. 4).

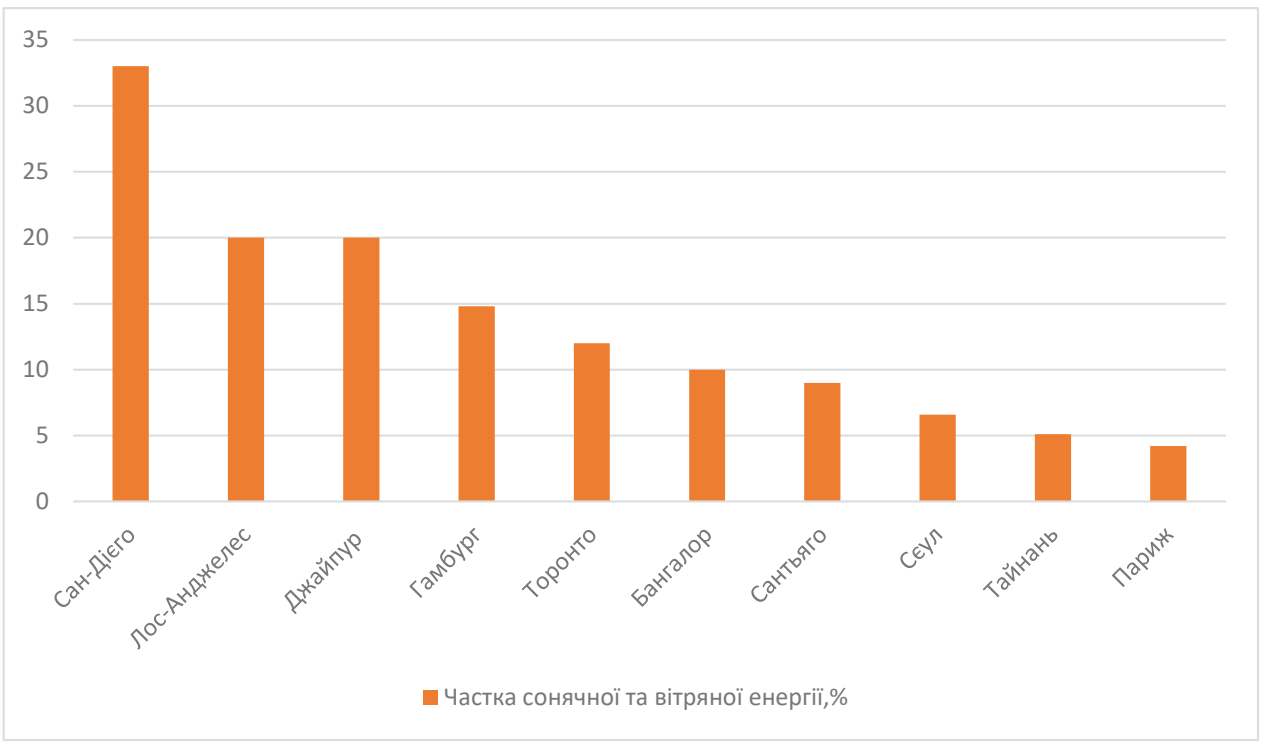

Рис. 4. Частка сонячної та вітрової енергії

у загальному обсязі генерації енергії в містах світу, 2018 рік 


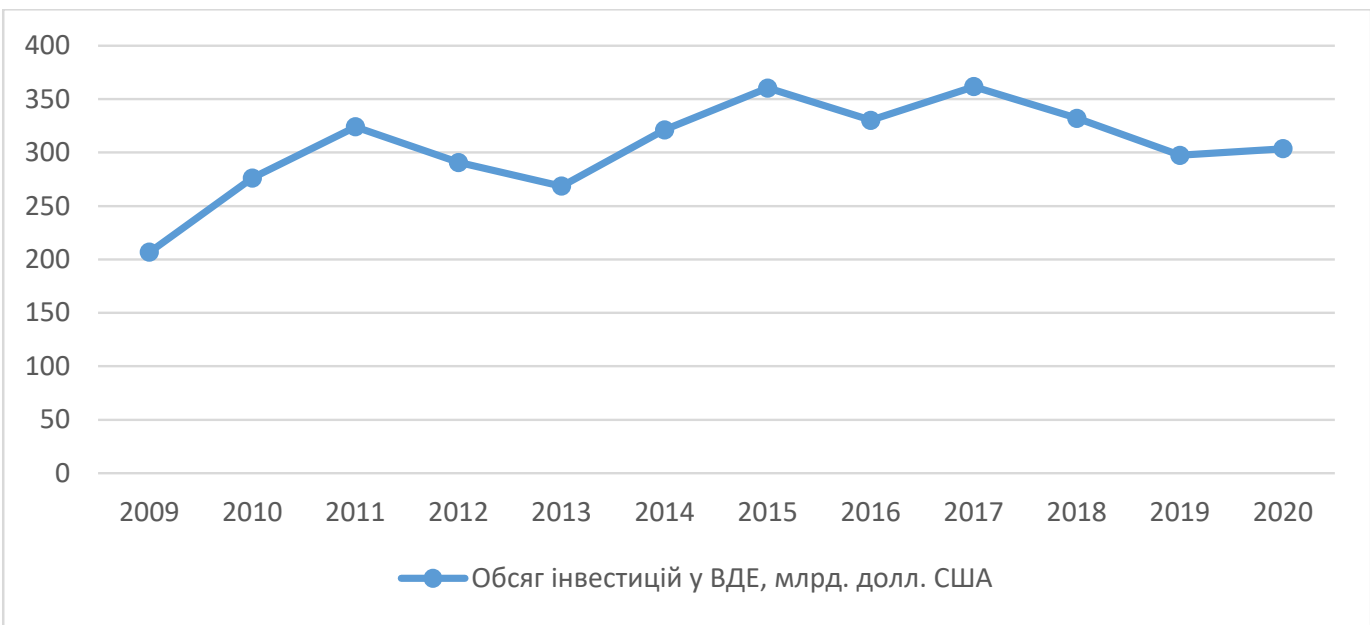

Рис. 5. Динаміка обсягу інвестицій у ВДЕ, 2009-2020 pp.

Джерело: створено авторами за даними [7]

«Розумне» місто - це місто, яке володіє сонячними та вітряними потужностями, а також планом розвитку, що поєднуе в собі ВДЕ-компоненти [6].

Одним зі стимулів до стрімкого переходу на джерела чистої енергії $є$ інвестування. Розглянемо динаміку інвестицій у ВДЕ за період 2009-2020 роки (рис. 5).

З рисунку 5 видно, що обсяги інвестицій у ВДЕ характеризуються коливаннями. Основними причинами цього є: падіння вартості технологій для забудови нових електростанцій, тобто надання переваги проектам з низькими капітальними витратами та позитивними прогнозами щодо повернення вкладених коштів; розрив у часі, а саме надходження інвестицій відбувається раніше, ніж новий об'єкт буде введений в експлуатацію; перевищення інвестицій у виробнищтво електроенергї 3 традищійних джерел (вугілля, природний газ, ядерне паливо); якщо кошти у ВДЕ надаються в якості державної підтримки, інвестування $є$ більш стабільним, а якщо приватними інвесторами, то менш стабільними.

Також, зазначимо, що після світової фрінансової кризи у 2008-2009 роках, спостерігається збільшення інвестищійних потоків у ВДЕ, оскільки відбувалося відновлення світової економіки до
2013 року. А у 2013 році тарифи на відновлювану енергетику почали знижуватися й інтерес бізнесу щодо інвестування в цю галузь економіки, тому відбувся перегляд контрактів на розвиток ВДЕ.

За даними дослідницької компанії BloombergNEF (BNEF) найбільшим регіоном, що інвестує у ВДЕ, є Свропа - 81,8 млрд доларів США, а країнами - Китай, США, Японія, Великобританія, Нідерланди, Іспанія, Бразилія, В’етнам, Франщія, Німеччина та Індія (табл. 1).

У 2019 році інвестиції в сонячну енергетику становили 130,77 млрд доларів США, а у вітрову - 151,26 млрд доларів США. У 2020 році показники склали 148,6 та 142,7 млрд доларів США відповідно. Тобто, інвестиції у сонячну енергетику збільшилися на $12 \%$, а у вітрову зменшилися на 6\%, порівнюючи з попереднім роком [7].

3 огляду вищевикладених даних, ми бачимо стрімкий розвиток сонячної та вітрової енергетики останніми роками. Виділимо причини такого зростання.

В першу чергу, зауважимо, що вартість генерації енергії в світі у цих двох напрямках 3 кожним роком стає нижче. У 2020 році цей показник можна зіставити 3 вартістю генерації традиційних (газової, атомної) енергій. Собівартість гене-

Таблиця 1

Найбільші країни за обсягом інвестицій у ВДЕ в 2020 році у порівнянні з 2019 роком

\begin{tabular}{|l|c|c|c|}
\hline \multicolumn{1}{|c|}{ Країна } & $\begin{array}{c}\text { Обсяг інвестицій } \\
\text { у 2019 році, } \\
\text { млрд дол. США }\end{array}$ & $\begin{array}{c}\text { Обсяг інвестицій } \\
\text { у 2020 році, } \\
\text { млрд дол. США }\end{array}$ & $\begin{array}{c}\text { 3міни в обсягу інвестицій } \\
\text { у 2020 році порівняно } \\
\text { 3 2019 роком, \% }\end{array}$ \\
\hline Китай & 93,63 & 83,6 & -12 \\
\hline США & 59,16 & 49,3 & -20 \\
\hline Японія & 17,37 & 19,3 & +10 \\
\hline Великобританія & 9,15 & 16,2 & +177 \\
\hline Нідерланди & 6,47 & 14,3 & +221 \\
\hline Іспанія & 8,4 & 10,0 & +16 \\
\hline Бразилія & 6,7 & 8,7 & +89 \\
\hline В'етнам & 0,81 & 7,4 & +38 \\
\hline Франція & 4,5 & 7,3 & +14 \\
\hline Німеччина & 6,1 & 7,1 & -36 \\
\hline Індія & 8,4 & 6,2 & \\
\hline
\end{tabular}

Джерело: створено авторами за даними [7] 
ращії енергії на сонячних електростанціях становить 29-55 дол. США, вітрових - 26-54 дол. США за мегават-годину. В той же час як газові електростанції- 28 дол. США, атомні - 29 дол. США, вугільні - 41 дол. США за мегават-годину. Якщо розглянути собівартість генерації сонячної енергії за регіонами світу, побачимо наступне: в країнах Азії - 47 дол. США, Свропи - 50 дол. США, Америки - 29 дол. США. Вітрова має наступні дані: країни Азї - 43 дол. США, Свропи - 34 дол. США, Америки - 23 дол. США.

Найближчим часом вартість генерації сонячної та вітрової енергії знижуватиметься ще на 15-25\%. Це досягається за рахунок новітніх технологій, котрі вже використовуються в цьому напрямку. Тому, використання вищевказаних електростанщій набуває більшої конкурентоспроможності та привабливості для інвестищій. Можна сказати, що зниження собівартості електроенергії спричинить менший дохід, але спираючись на подальший перехід людства на ВДЕ та науково-технологічний прогрес у цому напрямку сприятимуть зростанню інтересу у подальшому будівництві електростанцій [8; 9].
Ще однією причиною розвитку сонячної та вітряної енергії $є$ бажання інвесторів охопити якомога більший об'єм генерації, доки існує дефіцит енергії. Той хто перший заволодіє потужностями генерації та мережами постачання електроенергії, матиме можливість лобіювати свої інтереси.

Висновки. Отже, з проведеного дослідження можемо зробити наступні висновки. Починаючи з 80-х років минулого століття, особливо останні 20 років, проблема зміни клімату через шкідливі викиди парникових газів в атмосфреру, зокрема надмірне використання викопного палива, постала настільки гостро, що підштовхнула світ до переходу на ВДЕ. Повільний прогрес в цьому напрямку у 1990-х роках прискорився починаючи з 2009 року. Найближчим десятиліттям можна очікувати ще більше зростання частки сонячної та вітрової енергії у генерації загального обсягу електроенергії. Цьому сприятиме подальша потреба у переході на ВДЕ, задля запобіганню погіршення кліматичних умов, а також науковотехнологічний прогрес, який допомагає зниженню вартості генерації цих джерел енергій.

\section{Список літератури:}

1. Череп А.В., Циганок К.О. Альтернативні джерела енергї як засіб ресурсоефективності. URL: http://global-national.in.ua/archive/22-2018/130.pdf (дата звернення: 09.03.2021).

2. Нараєвський С.В. Порівняльний аналіз ефективності роботи сонячної та вітрової енергетики на світовому ринкy. URL: http://www.economy.in.ua/pdf/5_2019/9.pdf (дата звернення: 09.03.2021).

3. Офіційний сайт Enerdata. URL: https://www.enerdata.net/ (дата звернення: 09.03.2021).

4. Зміна клімату. URL: https://www.amnesty.org.ua/zmina-klimatu/ (дата звернення: 10.03.2021).

5. Чому і як міста по всьому світу рухаються до 100\% ВДЕ? URL: https://energytransition.in.ua/project/chomu-iiak-mista-po-vs-omu-svitu-rukhaiut/ (дата звернення: 10.03.2021).

6. Международные тенденщии в области возобновляемых источников энергии. Солнечно-ветровая энергия: больше чем мейнстрим. URL: https://www2.deloitte.com/content/dam/Deloitte/ru/Documents/energy-resources/Russian/ mezhdunarodnye-tendencii-v-oblasti-vozobnovlyaemyh-istochnikov-ehnergii.pdf (дата звернення: 11.03.2021).

7. Офіційний сайт дослідницької компанії BloombergNEF. URL: https://about.bnef.com/ (дата звернення: 11.03.2021).

8. Солнечная энергетика производит самую дешевую электроэнергии на многих рынках - WoodMac. URL: https://renen.ru/solnechnaya-energetika-proizvodit-samuyu-deshevuyu-elektroenergii/ (дата звернення: 12.03.2021).

9. Lazard`s levelized cost of energy analysis - version 14.0. URL: https://www.lazard.com/media/451419/lazardslevelized-cost-of-energy-version-140.pdf (дата звернення: 12.03.2021).

\section{References:}

1. Cherep A.V., Tsyhanok K.O. Alternatyvni dzherela enerhetycheskoy yak zasib resursoefektyvnosty [Alternative energy sources as a means of resource efficiency]. Available at: http://global-national.in.ua/archive/22-2018/130.pdf (accessed 09 March 2021).

2. Narayevskyy S.V. Porovnyalnyy analyzator éffektyvnosty roboty sonyachnoyi y vitrovoyi énerhetyky na svitovomu rynku [Comparative analysis efficiency of solar and wind energy on the world market]. Available at: http://www.economy.in.ua/pdf/5_2019/9.pdf (accessed 09 March 2021).

3. Official site of Enerdata. Available at: https://www.enerdata.net/ (accessed 09 March 2021).

4. Zmina klimatu [Climate change]. Available at: https://www.amnesty.org.ua/zmina-klimatu/ (accessed 10 March 2021).

5. Chomu y yak mista po vsemu svitu rukhayutsya do $100 \%$ VDE? [Why and how do cities around the world move to $100 \%$ RES]. Available at: https://energytransition.in.ua/project/chomu-i-iak-mista-po-vs-omu-svitu-rukhaiut/ (accessed 10 March 2021).

6. Mezhdunarodnye tendentsyy v vozobnovlyaemykh ystochnykov enerhyy. Solnechno-vetrovaya enerhyya: bolshe chem meynstrym [International trends in renewable energy. Solar and wind energy: more than mainstream]. Available at: https:/www2.deloitte.com/content/dam/Deloitte/ru/Documents/energy-resources/Russian/mezhdunarodnye-tendencii-v-oblasti-vozobnovlyaemyh-istochnikov-ehnergii.pdf (accessed 11 March 2021).

7. Official site of the research company BloombergNEF. Available at: https://about.bnef.com/ (accessed 11 March 2021).

8. Solnechnaya enerhetyka proyzvodyt samuyu deshevuyu élektroénerhyyu na mnohykh rynkakh - WoodMac [Solar energy produces the cheapest electricity in many markets - WoodMac]. Available at: https://renen.ru/ solnechnaya-energetika-proizvodit-samuyu-deshevuyu-elektroenergii/ (accessed 12 March 2021).

9. Lazard`s levelized cost of energy analysis - version 14.0. Available at: https://www.lazard.com/media/451419/ lazards-levelized-cost-of-energy-version-140.pdf (accessed 12 March 2021). 